\title{
Literature Review on Corporate Governance Practices and Bank Performance in Asia Emerging Markets
}

\author{
Hasroleffendy Hassan, Fauziah Mohamad Yunus, Chaleeda Som Sak
}

To Link this Article: http://dx.doi.org/10.6007/IJARBSS/v11-i12/11955 DOI:10.6007/IJARBSS/v11-i12/11955

Received: 11 October 2021, Revised: 14 November 2021, Accepted: 30 November 2021

Published Online: 19 December 2021

In-Text Citation: (Hassan et al., 2021)

To Cite this Article: Hassan, H., Yunus, F. M., \& Sak, C. S. (2021). Literature Review on Corporate Governance Practices and Bank Performance in Asia Emerging Markets. International Journal of Academic Research in Business and Social Sciences, 11(12), 2411-2436.

Copyright: @ 2021 The Author(s)

Published by Human Resource Management Academic Research Society (www.hrmars.com)

This article is published under the Creative Commons Attribution (CC BY 4.0) license. Anyone may reproduce, distribute, translate and create derivative works of this article (for both commercial and non0-commercial purposes), subject to full attribution to the original publication and authors. The full terms of this license may be seen at: http://creativecommons.org/licences/by/4.0/legalcode

Vol. 11, No. 12, 2021, Pg. 2411- 2436

Full Terms \& Conditions of access and use can be found at http://hrmars.com/index.php/pages/detail/publication-ethics 


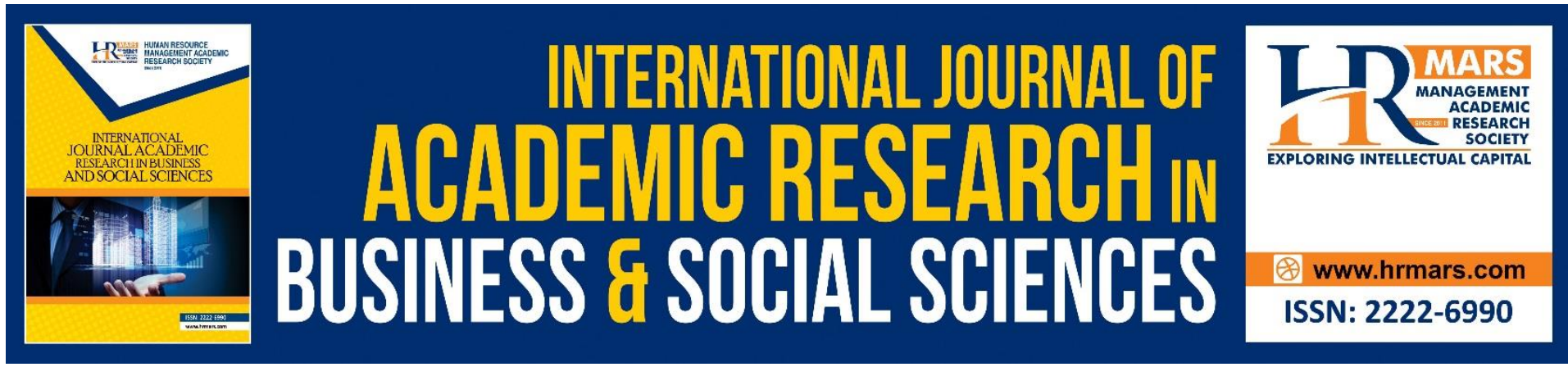

\title{
Literature Review on Corporate Governance Practices and Bank Performance in Asia Emerging Markets
}

\author{
Hasroleffendy Hassan, Fauziah Mohamad Yunus, Chaleeda \\ Som Sak \\ Faculty of Business and Management, Universiti Teknologi MARA Kedah Branch, Sungai \\ Petani Campus, 08400 Merbok, Kedah, Malaysia. \\ Corresponding Author: hasroleffendy@uitm.edu.my
}

\begin{abstract}
To date, there have been many studies performed to evaluate the impact of corporate governance on the performance of banks. Nonetheless, most of the previous research employed different sets of corporate governance factors and in fact, no paper had been accomplished on Asia emerging markets except a few studies that used Return on Asset (ROA) and Tobin's $Q$ to represent the performance of banks. There were only limited papers that investigated corporate governance against the performance of banks in emerging Asia but either in Southeast Asian economies only or in a single country. The past studies also took different periods as their time basis for data analysis and did not consider the improvements of corporate governance mechanisms especially the progress of guidelines issued by the Basel Committee of Banking Supervision (BCBS). Moreover, prior papers applied different formulas and models to derive bank performance whereby the majority of the theses employed profitability, instead of bank-specific performance measures to gauge the banks' performances. This paper explores the literature connected to this connection worldwide but particularly on banks operating in Asia emerging markets with emphasis on the 2007 financial predicament. Reviews of literature on non-bank corporations were also performed when the relevant studies on banks were not adequately done. Overall, the majority of the reviewed articles advocate the positive relationships between corporate governance practices and bank performance since the practices could safeguard the banks' resilience.
\end{abstract}

Keywords: Corporate Governance, Risk, Banking, Asia, Emerging Market.

\section{Introduction}

Most of preceding research that investigate the effect of corporate governance mechanisms on performance of banks employed normal corporate governance factors without any consideration for improvements of corporate governance nor for any corporate governance variables that might become critical and need further analysis after certain significant events such sub-prime crisis as well as banks' failures in Europe (Hassan et al., 2019). Furthermore, they did not really refer to the pertinent corporate governance mechanisms that recommended by BCBS via their periodical principles enhancements to improve corporate 
governance of banks. There were only several papers that examined certain corporate governance factors that were proposed by BCBS and seldom analysed by existing scholars, for example separate Risk Committee as well as banking and financial qualification for directors. Hence, this study discusses the following improvements mechanisms of corporate governance in banking institutions that were both highlighted in the past studies as well as suggested by BCBS' "Principles for enhancing corporate governance" (2010). These mechanisms which are exceptionally analysed in the preceding papers are combined with few existing mechanisms that are still applicable for banking institutions.

\section{Risk Governance and Bank Performance}

A report of OECD Steering Group on Corporate Governance that prepared by Kirkpatrick (2009) emphasized that prime responsibility of board is to ensure the integrity for risk management, and it concluded that the financial turmoil can be attributed to failure to safeguard against excessive risk taking in several financial institutions. This author referred to a report of Institute of International Finance (2008) which insisted for a review of Chief Executive Officer (CEO) and board roles in risk management process, apart from a solid risk culture throughout the firm. Moreover, a few members in the risk committee (or equivalent) should be individuals with financial sophistications in risk disciplines or with solid business experience, prioritizing on risk issues. A separation between risk and audit committees should also be considered (Hassan et al., 2019). It is worthwhile to note that beforehand, several audit committees in banks also perform risk management and control activities.

It is notable that research by Aebi et al (2012) utilised many corporate governance improvements mechanisms proposed by BCBS and infrequently analysed. The distinctive factors are existence of risk committee, meeting frequency of risk committee, number of directors in risk committee, percentage of independent directors in the risk committee, Chief Risk Officer (CRO) appointment in board and whether CRO reports to board directly. Apart from Aebi et al (2012); Hassan et al (2019) plus Ellul and Yerramilli (2013) also analysed the influence of the enhancements on performance of banks. Nonetheless, they did not investigate every single mechanism exclusively since they constructed a risk management index (RMI) from existence of CRO, CRO is an executive officer or not, CRO is among the five highest paid executives or not, the ratio of CRO's total compensation to CEO's total compensation, the board's risk committee experience in banking and finance as well as risk committee's meeting frequency. Their findings signify those banks with a high RMI value before the start of the financial crisis (2006) had lower risk, lesser exposure to problematic loans and better operating performance during the crisis years (2007 until 2008). Nevertheless, there was no relationship between RMI and stock returns during normal years. In a panel covering 1995 to 2010 period, they learnt that banks with high-protected RMI had, all else equal, lower tail risk and higher ROA. It is noteworthy that from risk governance perspectives, the other studies were not as comprehensive as Aebi et al (2012); Ellul and Yerramilli (2013) since most of them only employed less than three of the improvements in risk governance's features.

\section{Size of Risk Committee}

Kallamu and Saat (2014) as well as Erkens et al (2012) only took the establishment of risk committee (exist or not) as their independent variables for risk committee aspect whereby they did not go into details of the risk committee's characteristics. Erkens et al (2012) reported no significant relationship between the formation of risk committee and bank performance. 
Contrariwise, Kallamu and Saat (2014) highlighted that the establishment of risk committee improved market valuation of banking institutions whereas Aebi et al (2012) found that having a more steadfast risk committee with more frequent meetings, positively influence the banks' performances during the crisis. The findings were consistent with Battaglia and Gallo (2015) that also perceived the frequency of risk committee' meetings positively associated with market valuation of banks. Apparently, frequent yet practical risk committee meetings can avert various complications as well as can provide well-timed solutions before it is too late and problems worsen further.

Since there are not many past researches on the relationship between size of risk committee and bank performance, this section will review the preceding papers by discussing the associations with bank performance on board size, audit committee size and eventually, size of risk committee.

Concerning board size and bank performance, a number of previous research such as Boussaada and Karmani (2015); Rambo (2013); Staikouras et al (2007), together with Sakawa and Watanabel (2011) revealed negative relationship between board of directors' size and bank performance. This imply that optimal number of directors might contribute to better performance of banks but if it exceeds a certain perimeter, it might ultimately jeopardise banks performance. Conversely, several preceding papers such as Lukas et al (2015); Bokpin (2013) plus Ngwenya (2014) signify that larger board of directors contribute to better bank performance, which might be attributed by more variety of skills, knowledge and experience that collected from them.

About audit committee size, this is the most relevant committee to risk committee. It is noteworthy that only a few of past literatures examined the impact of disclosure on corporate performance as they mostly studied the impact of corporate governance mechanisms on disclosure quality. Al-Matari et al (2012) as well as Hsu and Petchsakulwong (2010) reported that audit committee size is negatively related to firm performance. They claimed that the negative relationship is in line with agency theory which states that firms will record worse performance when the number of a committee's members increases. Inversely, preceding papers namely Al-Matari et al (2014) as well as Swamy (2011) disclosed that performance of companies improved with larger audit committee. This might be consistent with resource dependence theory which underlines that a company performance could improve with larger board size.

Regarding the relationship between size of risk committee and bank performance, Romano et al (2012) concluded that control and risk (audit) committee should be smaller to enhance performances of banks. This paves the way for rising vigilance overboard decisions as well as activities and consequently, higher banks' profitability. Moreover, Romano et al (2012) also studied the impact of the proportion of independent risk committee against banks' performances. Unpredictably, they verified negative relationship between the percentage of independent directors in risk committee and banks' profitability in terms of both ROE and ROA. However, this result is obtained only using one model i.e. Fixed Effects with Robust Standard Errors.

On the other hand, Battaglia and Gallo (2015) discovered that banks with larger risk committee achieved better profitability but in contrast, size of risk committee was negatively associated with market valuation and the expected market growth of banks (Tobin's $Q$ and price earnings ratio). Additionally, Lee et al (2018) together with Zulkafli and Hassan (2020) also reported that the more effective control mechanisms can be attained via larger risk 
committee since the larger committee normally encompasses members with diverse expertise for effective oversight which could heads towards intensified banks' performances.

Premised on the above and since this governance mechanism was also proposed by BCBS in their 2010 guidelines under Key Area C-Risk Management and Internal Controls, Principle 7, there might be a significant relationship between size of risk committee and bank performance.

\section{Chief Risk Officer (CRO)}

Apart from OECD Steering Group report on Corporate Governance (2009) and Institute of International Finance (2008), the suggestions for CRO appointment on board to oversee all relevant risks within a bank are also raised by Brancato et al (2006); Sabato (2010) as well as (Banham, 2000). Hence, the appointment of a specific officer-in-charge (director's level) of risk management in a bank is of utmost importance.

Apparently, there are no earlier researches that examined the relationship between the appointment of CRO and performance of banks except papers by Aebi et al (2012) together with Ellul and Yerramilli (2013) notwithstanding growing number of banks that appoint CRO or equivalent, in tandem with recommendations by (BCBS, 2010). However, in a latest study, Lundqvist and Vilhelmsson (2018) disclosed that approximately 50 percent of their sample global banks had appointed CRO.

Aebi et al (2012) investigated the presence of a CRO in the executive board of a bank and they also researched the reporting line of a CRO i.e. whether he/she reports to Board or to CEO. They discovered that throughout the financial calamity, the stock returns do not differ significantly between the two types of banks and CRO appointment reduced the banks' stock returns. Nevertheless, banks with CRO demonstrated both higher ROE and ROA than banks with no CRO. Regarding the risk management variables, banks with a CRO significantly tend to have a more dedicated risk committee. Likewise, Ellul and Yerramilli (2013) also discovered that the presence of CEO in banks was significantly related to better bank performance. Hence, CRO in banks mostly implemented stronger risk management mechanisms which might contribute to banks better performances.

According to Lakhal et al (2015), generally, women are relatively more ethical than men and are also more likely to detect the manipulation of earnings to avoid the litigation and reputation risks. Furthermore, business case theory emphasises the importance of diversity management in business and advocates that greater corporate workforce diversity is always a catalyst for business growth. The diversity in the theory covers gender as well as nationality and encompasses all layers of human capital in a firm.

\section{CRO Gender}

Apart from BCBS suggestions, there have been many relevant authorities in several countries that require companies to promote gender balance on board. According to Setiyono and Tarazi (2014), the requirement has been in practice by Spain and France ( $40 \%$ by 2015 and 2017 respectively), Italian (30\% by 2015), and the Netherlands (30\% for each gender by 2016). They concluded that most of previous studies suggest that female directors are more connected to fewer risk taking as they are more risk-averse but there is also research that discovered otherwise.

Since there are not many past researches that specifically discuss the relationship between CRO background and bank performance, this and the following sections review the literatures on the relevant board diversities and performance, including non-banking corporations. In 
fact, there are not many prior literatures that investigated the effect of board gender diversity on banks (Kilic, 2015), thus definitely the studies on CRO gender is much lesser.

Regarding relationship between female directors and bank performance, Yu, Lenard, York, and $\mathrm{Wu}$ (2015) discovered that the presence of women board and executives decreased bank risk during financial crisis. Furthermore, banks' risks also declined when the percentage of women on the audit committee and corporate committee increased. The finding is consistent with $\mathrm{Yu}$ et al (2015) for USA, Shungu et al (2014) for Zimbabwe and Rambo (2013) for Kenya which discovered that board gender diversity improved financial performance of banks. The sample periods of all the above studies are during (before and after) the 2007 financial predicament. The above positive impact of gender on NIM might also in agreement with Hassan (2019) as well as Ittonen and Peni (2012) which suggests that female directors have more diligent approach to the monitoring role via membership on both corporate governance committees and audit committees.

Concerning study on the impact of female boards on non-bank performance, Stepanova (2012); Luckerath-Rovers (2013) reported that female directors significantly improve performance of companies as well. Bart and McQueen (2013) together with Luckerath-Rovers (2013) suggest that women might appear to make better directors than men. Bart and McQueen (2013) opined that female director might produce more effective decisions because they have highly developed Complex Moral Reasoning (CMR) skills than male directors.

Hence, female CRO is indeed vital for better corporate governance practices and ultimately, banks' enhanced performances.

\section{CRO Nationality}

It is generally expected that foreign directors will not only bring broader networks but international perspective and experience as well, to the recruiting banks (Setiyono \& Tarazi, 2014). Piekkari and Vesanen (2009) emphasised that board internationalization should involve fulfilling missing needs of competence instead of satisfying a specific geographical requirement. Additionally, it will be more effective if a foreign director can communicate well with all stakeholders.

Polovina and Peasnell (2015) opined that there are contradictory findings regarding appointment of foreign directors on performance of companies. They could contribute in term of more effective monitoring and better management. Nevertheless, their personal motivations and incentives might result in worse performance.

Agrawal and Knoeber (1996) discovered that local CROs contribute to better bottom lines of corporations under review which was might be due to their familiarities with the local industry's operations and regulations. In contrast, Nielsen and Nielsen (2013) together with Ujunwa (2012) found that nationality diversity is positively related to firm performance. The presence of foreign board members promotes well-organized monitoring with reduced agency costs in a company. Likewise, Tee et al (2016) also discovered that the rising numbers of foreign directors on Malaysia listed firms could enhance the companies' performances but they could not find any evidence on the impact of foreign chairman and foreign CEOs.

Regarding banking institutions and based on Olubukunola et al (2016), foreign directors are expected to improve the advisory role of boards of banks due to their direct information about international markets together with their diverse backgrounds but they reminded that the roles of foreign independent directors should not be overemphasized. Furthermore, there are mixed findings as well, on the impact of board nationality and bank performance. 
Zigraiova (2016) reported that more foreign directors could increase bank risk and could decrease bank stability. Moreover, the effect of foreign directors was not significant for building saving societies, large banks, and better capitalized banks. Likewise, Setiyono and Tarazi (2014) also discovered that nationality diversity is associated with higher risks in banks and eventually could decrease bank performance. Based on Kilic (2015), most of the banks in Turkey registered worse financial performance when they appointed more foreign directors. These could be owing to lack of familiarity with local banking environment together with language and cultural barriers (European Commission, 2010).

Additionally, there are unique findings of Polovina and Peasnell (2015) which divided their analysis on three types of appointments namely foreign CEO, foreign director, and foreign chairman. They reported that foreign CEO and foreign director were not significantly related with bank performance, which might be driven by their personal motivations and incentives. In contrast, foreign chairman boosted profitability of banks in Turkey as they might be more independent when advising the board as they have less conflict of interest with the local directors. Similarly, results of Sunday and Godwin (2017) together with Abu, Okpeh and Okpe (2016) disclose that board globalization and diversity, including foreign directors, significantly enhanced bank performance. They further recommended for bank management to increase the number of foreign directors until a certain limit, as they have valuable expertise and experience from at least one different country. The foreign directors normally always protect their integrity, reputation and professional competence.

Therefore, apart from only analysing the effect of CRO gender on bank performance, their nationality is also pertinent to ensure their better contributions on better corporate governance practices and eventually, for better performance of banks.

\section{Reporting Line of CRO}

Aebi et al. (2012) clarified that if a CRO is a member of the executive board, his influence and power are expected to be more superior as against a CRO who is on the third management level. However, it is essential to note that a powerful CRO is not necessarily leads to growing bank value provided he/she should recognize the remarkable risks and able to induce the indispensable reduction in risk exposure and concentrations (Zulkafli \& Hassan, 2020).

Aebi et al (2012) discovered that banks in which the CRO reports directly to the board of directors performed significantly better during the credit crisis than other banks in which CRO did not report directly to their boards.

Conversely, banks in which the CRO reports to the CEO instead of board, performed significantly worse which might conform to Aebi et al (2012) that a CEO might have different agenda than a CRO, which neglecting the prominence of effective risk managements. Moreover, the CEO might also over emphasize the assets growth without a defined risk appetite strategy.

This signifies that line of reporting of a CRO is vital to the banks' crisis performance. These empirical results were consistent with many earlier studies that also emphasised the importance of effective reporting line from CRO to the Board, namely Mongiardino and Plath (2010), Sabato (2010) as well as (Ellul and Yerramilli, 2013). They discovered that efficient and independent risk management including $\mathrm{CRO}$ and risk committee characteristics, can restrain tail risk exposures and enhance value of banks, predominantly during crisis.

In addition, Elamer and Benyazid (2018) highlighted that effective risk committee and CRO (which includes reporting line) make more pressures over banks management to strengthen the quality of risk management implementations. Moreover, these also improve 
communication concerning risk management among different stakeholders; including management and board to reduce agency conflicts. Considering the above and given that this governance mechanism was also proposed by BCBS in their 2010 guidelines under Key Area C-Risk Management and Internal Controls, Principle 6, there is a possibility of significant positive relationship between reporting line of CRO and bank performance.

\section{Board Governance and Bank Performance Board Qualifications and Experience in Banking and Finance}

Another corporate governance aspect that is also comparatively new and vital for banking corporations is qualification plus background of directors in banking/finance, to ensure banks are steered by more competent directors. Kallamu and Saat (2015); Erkens et al (2012) together with Aebi et al (2012) were more specific as they scrutinized the corporate governance aspect in more details by focusing on financial qualification and background amongst directors of banks. As a result of several corporate accounting frauds worldwide, most regulators raise their emphasis on the importance of having financial experts on the board of directors. Aebi et al (2012) explained that according to the Sarbanes-Oxley Act of 2002, a financial expert has among other things "an understanding of generally accepted accounting principles and financial statements". Aebi et al (2012) defined directors with finance background as directors with experience (present or past) as an executive officer in a bank or insurance company, mutual fund, hedge fund or Certified Public Accountants (CPA), Chartered Financial Analysts (CFA) or private equity fund managers, REIT managers or professors in finance, economics and accounting. Nevertheless, Erkens et al (2012) had simpler but broader definition i.e. directors that either has a CFA/CPA or has worked in accounting or finance functions. Pertaining to Kallamu (2015), they scrutinised the financial qualification and background attributes amongst audit committee only, based on finance qualification of audit committee together with finance industry experience of the committee. It is worthwhile to note that only Aebi et al (2012); Kallamu (2015) produced similar findings whereby financial qualification and background of directors negatively affect performance of banks and these findings unexpectedly refutes the contemporary requirements or suggestions for banks to have more financial experts on the board of directors to enrich the banks' achievements. Nonetheless, this is corresponding to the findings of Minton et al (2014). They emphasized that the level of financial expertise among directors is positively correlated to risk taking, both before and during the financial disaster in spite of being consistent with shareholders' value maximization objectives. For that reason, their sample banks registered better stock performance before the crisis but then poorer performance throughout the financial calamity. However, it is notable that they opined that the detrimental results were not actually caused by incompetent financial professionals on board but attributable to chief executive officers who merely selected independent financial experts who could rubber stamp strategies that satisfy their risk appetite. Conversely, Erkens et al (2012) revealed that financial qualification and background of directors were insignificantly associated with performance of banks. This might be owing to much larger sample of banks in their literature.

On the other hand, Tarraf and Majeske (2013) as well as Peni and Vahamaa (2012) only investigated on the general education and background of banks' directors. Both studies used Corporate Governance Index (Gov-score) developed by Brown and Caylor $(2006,2009)$ to gauge the strength of banks' corporate governance and the Gov-score index is based on 51 firm-specific features that measure internal and external firm's governance level. The varied governance segments measured in the Gov-score are auditing, board of directors, 
charter/bylaws, director education, executive and director compensation, ownership, progressive practices and state of incorporation. Tarraf and Majeske (2013) discovered that the wide-ranging banking governance system under Gov-score including the general education and background of banks' directors did not significantly influence risk taking of banks but risk taking indeed affected their performances. Consistent with prospect theory, behavioural agency model and past literatures, the paper demonstrates that during the crisis, banks with lower risk had better performances than banks with higher risk.

Regarding Peni and Vahamaa (2012), their results are mixed between three performance methods namely ROA (profit), Tobin's Q (value of banks) plus stock returns as well as two periods i.e. during and after financial catastrophe. Remarkably, Peni and Vahamaa (2012) discovered that good corporate governance did not improve the stock market performance of banks during the financial crisis as banks with stronger governance recorded lower value of banks as well as lower stock returns throughout the calamity. Their findings make it apparent that good corporate governance did not create shareholders' value amongst banking firms during the market collapse. Nevertheless, the study disclosed that amidst the financial disaster, high scores of corporate governance under Gov-score including the general education and background of banks' directors intensify banks' profitability significantly, suggesting that good governance may had moderated the severe effects of the financial tragedy on financial performance of banks. Nevertheless, Peni and Vahamaa (2012) highlighted that banks with superior corporate governance mechanisms disclosed substantially greater stock returns after the financial disaster, from March 2009 onwards. This outcome points out that at the very least, good corporate governance implementations may had alleviated the unfavourable perceptions of the crisis on banks' credibility among stock market participants. In other words, the participants might be optimistic that the good governance of banks will enhance their resilience in the near future and this optimism might be partially attributed by convincing qualification and background of the banks' directors.

Srivastav and Hagendorff (2015) emphasised that the expertise and previous relevant experience of directors can have positive attitude on bank risk-taking. They advocate that future research should investigate the financial expertise of board members and relate it to bank risk-taking and also performance. Kirkpatrick (2009) emphasised that lack of financial expertise on bank board is the key factor in the 2007-2008 financial crisis. Apparently, corporate governance aims to resolve the principal-agency problem and one of the measures to rectify the problem is the involvement of independent directors, as suggested by agency theory. Sufficient knowledge and understanding of directors is necessary in order for them to make rational and reasonable judgement (Zulkafli et al., 2020). Their understanding of business environment, markets, product and key financial information is essential. Otherwise, they can be easily manipulated and/or unknowingly making irresponsible material decisions (Law Teacher, 2013). It is also noteworthy that these corporate governance mechanisms were already recommended by BCBS in their 2010 guidelines under Key Area A-Board Practices, Principle 2. Accordingly, there are possibilities of significant positive impact of directors' qualifications as well as experience in banking/finance on bank performance.

\section{Board Independence}

Directors are the most vital personnel in any corporation as they are assigned with delegated authorities by the shareholders to formulate policies, safeguard internal control, evaluate as well as compensate the top management to boost the competence of the corporation (Hoque et al., 2013). Consequently, the success of a firm mostly depends on the optimal composition 
of board encompassing non-independent and independent directors (Zulkafli et al., 2020). According to Financial Stability Board (FSB) (2013), an independent director basically refers to a member of the board who does not have any management responsibilities with the firm and is not under any other undue influence that would impede the director's exercise of objective judgement.

FSB (2013) also provides further details on the regulatory and supervisory guidance for the composition of the independent board and sub-committees. Some of the key features that FSB emphasizes include that "Many jurisdictions also set out quantitative minimums for the number of independent directors on the board. Some other jurisdictions only set quantitative minimums for the number of non-executive directors which does not necessarily ensure independent judgement on the board".

Most regulatory efforts and market best practices worldwide have concentrated on the issue of independence board post the 2007 financial crisis and even before the financial predicament (Aguilera, 2005). Examples of the said countries are United Arab Emirates (UAE) (Al-Tamimi, 2011), Bangladesh (Hoque et al., 2013), Malaysia (Kallamu, 2015), Italy (De Andres and Vallelado, 2008) together with Egypt (Grant Thornton, 2010).

BCBS (2006) together with Walker (2009) Report also underscored particularly on the role of independent directors stating that their role is (i) to ensure that there is an efficient executive team in a bank, (ii) to participate actively in the decision-taking process of the board and (iii) to oversight appropriately over execution of the approved executive strategy.

Empirically, majority of the earlier papers on the relationship between board independence and firm (bank and non-bank) performance disclose that there was solid association between board composition and market valuations of emerging market companies. Findings suggest that companies with higher fraction of outsider/independent directors usually have a higher valuation and must reach a certain threshold to be effective (Claessens \& Yurtoglu, 2013). Overall, results suggest that board independence plays important roles in developing countries and emerging markets, where other control mechanisms on insiders' self-dealing are weaker (Hassan et al., 2018).

These findings are in line with Chiang (2005) who argues that independent directors are more specialized to monitor the board than the executive directors in running successful firms. This objective can be achieved by reducing the concentrated power of the chief executive, whereby it supports the firms to prevent misuse of resources and simultaneously, enhancing performance. Moreover, higher proportion of independent directors also helped in preventing expropriation through related party transactions (Lo, Wong, \& Firth, 2010).

In contrast, directors who are unrelated to the firm may lack the knowledge or information to be effective monitors (Hoque et al., 2013). De Andres and Vallelado (2008) highlighted that an excessive proportion of independent directors could damage the advisory role of boards since executive directors facilitate the transfer of information between directors and management. Pertaining to the connection between independent directors and performance of the banking institutions, prior related theses revealed mixed results i.e. almost balanced findings between significant and insignificant outcomes. Interestingly, both contrasting results were mostly documented in emerging markets but majority of the theses utilised sample banks from single countries. Ngwenya (2014) for South Africa, El-Chaarani (2014) for Zimbabwe, Dincer (2012) for Turkey, Nyamongo and Temesgen (2013) for Kenya, Rowe et al (2011) for China together with Hoque et al. (2013) for Bangladesh discovered that quantity of independent directors significantly enhanced banks performances in the countries throughout the related periods under review. Six of the studies employed ROA and ROE as the measures of bank performance. 
Contrariwise, only Hoque et al (2013) added Tobin's Q as additional measure whilst Tanna et al (2011) engaged cost and profit efficiency measures.

From the above, only Ngwenya (2014) as well as El-Chaarani (2014) examined the relationship between board independence and bank performance after the 2007 financial crisis i.e. from 2009 until 2011 and from 2009 until 2012 respectively, whereas Nyamongo and Temesgen (2013); Dincer (2012) together with Hoque (2013) selected more wide-ranging time period that covers pre, during and post 2007 financial disaster.

In contrast and to the best of the author's knowledge, only Erkens et al (2012) documented that board independence significantly decrease bank performance in its selected samples. The paper utilised one of the biggest samples i.e. 296 listed financial firms from 30 countries that were at the centre of the crisis (January 2007 to September 2008). However, more than 85\% of the selected banks were from developed countries namely the US and European countries. The study discovered that banks with more independent boards' ownership experienced worse stock returns during the crisis period. They opined that banking institutions with more independent boards raised more equity capital during the crisis, which led to a wealth transfer from existing shareholders to debtholders.

Minton et al (2014) investigated the impact of independent directors against risk taking and US banks performance from 2003 until 2008 but in term of financial experts amongst the independent directors. The paper found that stock performance for large banks with more independent financial expertise was worse during the crisis, due to the heightened risk profile. The study claimed that the results could be explained by the fiduciary duty of independent financial experts to shareholders who favour more risk taking and participate in more risktaking activities due to their familiarity with complex financial instruments.

Several preceding papers that employed bank data from most emerging markets documented that the proportion of independent directors did not significantly affect bank performance. The said findings are discovered by (Boussaada and Karmani, 2015; Wasiuzzaman and Gunasegavan, 2013; Praptiningsih, 2009; Bokpin, 2013; Aebi, 2012; Al-Tamimi, 2012; Battaglia, 2015). Amongst the above papers, only Aebi (2012) examined the above relationship in developed nations i.e. Europe and the US respectively. On the contrary, the other above studies used data from banks in emerging markets namely Middle East and North Africa (MENA) region (Boussaada and Karmani, 2015), Malaysia (Wasiuzzaman \& Gunasegavan, 2013), South East Asia (SEA) region (Praptiningsih, 2009), Ghana (Bokpin, 2013), UAE (AlTamimi, 2012) as well as China and India (Battaglia, 2015). Six papers from the above either using ROA and ROE or both measures whilst Aebi (2012) used buy-and-hold stock return and Battaglia (2015) utilised the most comprehensive performance measures which consist of Tobin's $Q$, ROA, ROE and price-to-earnings ( $P / E$ ) ratio.

Agency theory emphasises that independent directors helped to alleviate agency problem by monitoring and controlling the behaviour of management (Fama and Jensen, 1983; De Andres and Vallelado, 2008). This underlines that an outside director has an incentive to portray good reputation as an "expert caretaker" who is more likely to take proper control of a firm (Hassan et al., 2018). Moreover, it is also notable that this governance mechanism had also been suggested by BCBS 2010 guidelines under Key Area A-Board Practices, Principle 3. In line with all the above, there might be a significant positive relationship between independent directors' majority and bank performance.

\section{Disclosure and Transparency Governance and Bank Performance}

It is apparent that one of the OECD's vital principles of corporate governance is: 
"The corporate governance framework should ensure that timely and accurate disclosure is made of all material matters regarding the corporation, including the financial situation, performance, ownership, and governance of the company."

That means the first rule is on the disclosure content to ensure that all pertinent information is included in the relevant disclosures. Besides verifying that the financial statements impartially represent the financial position of a company, the audit statement should also include an opinion on the way in which financial statements have been prepared and presented (OECD, 2004). Accordingly, BCBS has also been highlighting disclosure and transparency governance as one of the key areas in its guidelines of bank corporate governance, even before the 2007 financial predicament (Basel, 2006).

Corporate disclosure is crucially important for the growth and development of a firm in particular and equity market in general (Akhtaruddin \& Haron, 2010). Gul and Leung (2004) claimed that disclosure is an obvious prerequisite for an equity market to function more efficiently. The current globalisation of stock market and convergence of accounting standards have raised the demand of capital market participants for enhanced information, beyond the minimum statutory requirements in order to facilitate the decision-making process (Berradino, 2001) (Hassan et al., 2018). In general, disclosure incorporates release of financial and non-financial information, details involving directors and key executives, management discussion together with analysis and forward-looking information (Ho \& Taylor, 2013).

Disclosure is predominantly vital for banking industry since banks are generally viewed as being opaque to outsiders. In fact, one of the most supreme guidelines for disclosure by bank is 2004 OECD principles since BCBS (2010) recommended that banks should apply the disclosure and transparency section of the 2004 OECD principles, apart from similar sections in BCBS guidelines. Based on the two documents, disclosure should include, but not be limited to, material information on the bank's objectives, organisational and governance structures together with policies, major share ownership and voting rights as well as related parties transactions.

Concerning risk-perspective disclosure guidelines, bank should also "disclose key points concerning its risk tolerance/appetite (without breaching necessary confidentiality), with a description of the process for defining it and information concerning the board involvement in such process. Fundamentally, bank must disclose everything that seems to be related to risk that might encompasses risk objectives, risk management practices and outcomes of the risk practices. It means that bank cannot hide anything that can be connected to risk since the 2007 financial crisis could be attributed to flaws in corporate governance arrangements, which did not serve the purpose to safeguard against excessive risk taking in various financial institutions (Isaksson \& Kirkpatrick, 2009, OECD Steering Group on Corporate Governance; Battaglia \& Gallo, 2015). Another prominent recommendation in 2004 OECD principles which was not underlined in BCBS (2010) is "disclosure should include, but not be limited to, material information on foreseeable risk factors". The word "foreseeable" means bank should not only disclose matters that related to past and present risks but also things that might pave the way for risk occurrences in the future.

It is notable that only a handful of literatures examined the impact of disclosure on corporate performance (Jo \& Kim, 2008). Amongst the preceding papers that investigated the impact of disclosure on performance of non-bank corporations in a group of countries in emerging regions is Abd. Rahman et al (2009). Nonetheless, the paper analysed the effect of environmental disclosure only, whereby the paper used "detailed environmental reporting" term to define situations where companies discuss and explain in detail (one paragraph or 
more) their environmental activities and commitments in their annual report. They included data from listed environmental reporting firms in three countries of southeast Asia only, i.e. Malaysia, Thailand and Singapore. The study demonstrates that Malaysian companies contain the highest number of disclosure whilst Singapore has the smallest number of companies that disclosed environmental commitments despite its developed status. Overall, findings indicate that production of detailed or superficial environmental disclosure, or both was not associated with the performance of the companies. This might be due to the composition of environmental disclosure details which is not really related to most of firms' business operations.

Nor et al (2016) also analysed the connection between environmental reporting and firm performance but for top 100 listed firms as of 2011, in Malaysia only. The companies emphasized the disclosure of their contribution in environmental activities to attract investors as well as to fulfil stakeholder's demand. In contrast with Rahman et al (2009), Md Nor et al (2016) discovered significant positive relationship between total environmental disclosure and profit margin. The insignificant relationship that obtained by Abd. Rahman et al (2009) most probably due to period of study i.e., way back in 2010 whereby most companies in the selected countries were still not concerned on environmental issues including the related disclosures. Nevertheless, Nor et al (2016) also reported insignificant relationship between total environmental disclosures and other three variables which are ROA, ROE and EPS.

Bazrafshan et al (2015); Khlif et al (2015), along with Elkelish and Hassan (2015) also examined the association between disclosure and non-bank corporations for companies in emerging markets. However, the theses employed data only from single or two selected countries in the said region. Using data from firms in South Africa and Morocco spanning from 2004 to 2009, Khlif et al (2015) also studied the effect of environmental disclosure on company's performance. They documented that social and environmental disclosures significantly enhanced corporate performance (measured by Tobin's Q) in South Africa but unpredictably, similar type of disclosure practices significantly diminished financial performance of corporations in Morocco although both are African countries. The paper stated that the different findings most probably due to the different legal origin and prevailing institutional settings in each country, i.e. power to impose regulations on companies to incorporate social and environmental considerations into their business operations.

Bazrafshan et al (2016) documented those corporate disclosures by firms in Hong Kong boosted financial performance of firms throughout 2006 until 2013 and the impact was stronger in firms with more independent directors on board. However, after an optimum level, increasing disclosure impaired firms' performance. They opined that concentrated monitoring by CEOs offsets the advantage of additional corporate disclosure. High disclosure means more exposures on CEO's activities, part of which CEOs does not want to reveal.

Based on public listed corporations in UAE during 2008-2009, Elkelish and Hassan (2015) employed a unique and seldom used measure for firm's performance i.e. share price accuracy. A low accuracy level means all of the movement in company returns is explained by market and industry returns, rather than by company-specific information and vice-versa. The article found that both voluntary and mandatory corporate governance disclosure had a significant positive impact on share price accuracy for companies in UAE. This is consistent with the theoretical predictions of the Positive Accounting Theory (PAT), which explain companies' disclosure strategies in terms of the economic consequences.

In comparison, banks in emerging nations such as Gulf Corporation Council (GCC) are relatively smaller in size and have lower disclosure levels compared to international banking standards. 
For instance, the annual reports by GCC banks in few countries do not contain clear information on board members independence level. Nevertheless, majority of emerging countries had disclosure levels that were almost at par in comparison with the more developed nations (Kallamu, 2015). Meanwhile, in Islamic banks, Ginena (2014) discovered inadequate disclosure or transparency and such scenarios were obvious in the wake of the financial crisis. According to Hassan et al (2012), annual reports of few Islamic banks normally lack much needed transparency on some of the most fundamental facts like the number of meetings held and resolutions passed.

To the best of this author's verifications, only Praptiningsih (2009); Hirtle (2007) performed the analysis of relationship between disclosure and bank performance but on two remarkable different populations. Praptiningsih (2009) employed data from southeast Asia countries (Indonesia, Thailand, Philippines and Malaysia) pre and onset 2007 financial crisis phase i.e. 2003-2007 whereas Hirtle (2007) analysed data of active-listed US-owned bank holding companies (BHCs) over 1994 to 2004 i.e. way before the financial distress. In Praptiningsih (2009), the disclosure monitoring mechanisms through big four external auditors were significantly affected ROA of the selected banks instead of the rating of the banks by big three rating agencies. The study highlighted that the findings were slightly contrast with the expectation and it mostly attributed by the early stage of adoption for good corporate governance by the banks. Nevertheless, it is noteworthy that based on comparisons by Praptiningsih (2009), this result is similar for the same research done on non-banking firms in the same region, which means that disclosures by big four external auditors for the non-bank corporations significantly improved their financial performance.

Hirtle (2007) examined the relationship between the amount of information disclosed by BHCs and their subsequent risk profile and performance, measured by equity market returns. This is a Staff Reports of Federal Reserve Bank of New York but not necessarily reflective views of the bank and its associates. Based on data from the annual reports of BHCs with large share trading operations, the paper created an index of publicly disclosed information of the BHCs' future estimates of market risk exposure in their trading activities. They only selected BHCs with significant trading activities since these firms were most likely to disclose market-riskrelated disclosures in their annual reports. Overall, the main results of this analysis show that disclosing more information was associated with lower risk, especially idiosyncratic risk, and in turn higher risk-adjusted trading returns and higher risk-adjusted market returns for the banks. These findings suggest that greater disclosure was associated with more efficient risk taking and thus improved risk-return trade-offs. Consequently, disclosing more information contributed for better performance via improved risk-return trade-off, as long as the disclosed information was within the range of what other BHCs disclose i.e. the optimal disclosure level. This is consistent with Bazrafshan et al (2016) which also documented that firm performance decreased when disclosure level is too high i.e. there was an optimal level of disclosure and CEOs' costly and counterproductive efforts to distort information, dominates the impact beyond the optimal level.

Furthermore, OECD also provides particular attention on the audit aspect:

"An annual audit should be conducted by an independent, competent and qualified auditor in order to provide an external and objective assurance to the board and shareholders that the financial statements fairly represent the financial position and performance of the company in all material respects".

Consequently, apart from in-depth scrutiny on the level of information in disclosure, the second rule is to ensure that all parties involved in the disclosure preparation is independent 
and competent. This is in line with Okoi et al (2014) which emphasised that the quality of information in disclosure depends on the standard and practices under which it is prepared and presented. Apart from external auditors, the key parties that involved in the said preparation is audit committee members. Kallamu (2015) highlighted that the expertise of an audit committee contributes significantly for quality disclosures. Therefore, rather than only analysing the relationship between typical disclosure details and bank performance, alternatively, this article concentrates on the caretakers of disclosure and feeders of disclosure details to the external auditors i.e. the audit committee.

Many countries have implemented measures to improve the independence of auditors and to tighten their accountability to shareholders as well. Several countries are restricting audit oversight or supervision of audit through an independent entity. Therefore, OECD (2004) has recommended for corporations to ensure that their audit committee is oversighted by independent committee, which is generally known in many firms as audit committee. Nonetheless, at present, a number of audit committee in many corporations are not completely independent. In view of higher risk profile of banks compared to non-bank corporations, it will be better for them to have a wholly independent audit committee. In addition to audit committee independence per se, banking institutions must also ensure that their independent audit committee comprises truly competent committee (as proposed by OECD) which could possibly contribute more to their resilience in light with more challenging business environment coupled with highly regulated nature of banking industry (Hassan et al., 2014).

\section{Audit Committee Full Independence}

The Principles of Auditor Oversight issued by International Organization of Securities Commissions (IOSCO in 2002) states that "effective auditor oversight generally includes, inter alia, mechanisms: to provide that a body, acting in the public interest, provides oversight over the quality and implementation, and ethical standards used in the jurisdiction, as well as audit quality control environments; and to require auditors to be subject to the discipline of an auditor oversight body that is independent of the audit profession, or, if a professional body acts as the oversight body, is overseen by an independent body" (OECD, 2004).

The audit committee or an equivalent body should not only be specified as providing oversight of the internal audit activities (Hassan et al., 2018). However, it should also be allocated with supervision of the overall relationship with the external auditor including the nature of nonaudit services provided by the auditor to a company. OECD (2004) states that provision of nonaudit services by the external auditor to a corporation can significantly jeopardise their independence. Moreover, Ghafran and O'Sullivan (2013) discovered that independent audit committee preserves the independence of the external audit by purchasing less non-audit services from their external auditor.

There were several prior studies that underscored the advantages of having independent audit committee. Ismail, Dustan and Zijl (2009) stressed that independent audit committee performs better than less independent committee as the more independent team is anticipated to provide more monitoring due to its ability to resist pressure from the management. Additionally, Woidtke and Yeh (2013) testified that completely independent audit committee as well as audit committee with majority independent member is associated with improved comprehensive details of a firm's accounting earnings. It is worthwhile to note that audit committee must not only have majority of independent directors but being completely independent (Hassan et al., 2018). 
In this section, this author did not rigidly look into the relationship between independent audit committee and firm performance per se, as many accounting-based studies investigated the effect of the committee's independence against financial reporting quality and earning practices instead of only performance. Moreover, there were not many papers that examined similar linkages for banks. It is apparent that majority of past studies that documented significant relationships between audit committee independence and firms' (banks and nonbanks) performance were conducted in emerging markets but each paper only selected single country from the said regions. Probably, there were less significance of such relationships in the developed countries because corporations in the advanced nations already applied the majority or completely independent audit committee. This condition might coincide with Kusnadi et al (2015) which did not find evidence that incremental independence of audit committees in Singapore could enhance financial reporting quality, if audit committees already comprised majority of independent directors. Furthermore, this might also be related to Nuryanah and Islam (2011) which stated that the traditional findings on the relationships between corporate governance mechanisms and company performance in developed countries, might be different for emerging markets like Indonesia where the business environment is different. For example, the capital market is still under-developed and the regulatory framework is normally relatively weaker.

The articles that found significant positive relationship between independent audit committee and financial reporting quality/performance of non-bank firms in emerging markets were Yasser et al (2011) for Pakistan, Akhtaruddin and Haron (2010) for Malaysia as well as Siagian and Tresnaningsih (2011) together with Nuryanah and Islam (2011) for Indonesia. All the above papers studied the relationship way before the 2007 financial catastrophe except for Yasser et al (2011) which employed data during the crisis i.e. from 2008 until 2009.

In term of the linkages between independent audit committee and firm performance, Yasser et al (2011) documented that independent audit committee positively affect ROE and profit margin of companies whilst the audit committees in the companies must have right combination of independent and non-independent directors. Using a panel data during 2002 until 2004, Nuryanah and Islam (2011) found that audit committee independence was one of the main attributes of corporate governance that enhanced company's performances that were measured by Tobin's Q. They also highlighted that unpredictably, the advantages of several special aspects of internal corporate governance practices in developed countries such as having accounting expert on audit committee, did not occur in Indonesia.

De Vlaminck and Sarens (2013) together with Chan and Li (2008) also reported that firms having audit committee independence significantly improved their performances, but the researches were executed in developed countries. The empirical study of De Vlaminck and Sarens (2013) did not compare audit committee independence against firm performance but to financial statement quality of companies in Belgium throughout 2008 till 2009. The paper demonstrates positive and significant association between the proportion of independent audit committee members and the quality of financial statement.

Similarly, Chan and Li (2008) also defined top executives of other publicly traded firms as expert-independent directors for top 200 publicly traded Fortune 500 firms in 2000 . The study found that performance of companies (measured by Tobin's Q) was positively impacted by the presence of the expert-independent directors on audit committee. The article also reported that an audit committee that encompasses a majority of finance-trained directors enhanced firm value almost five times more, against firms with ordinary independent audit committee only. It is worthwhile to note that without majority control of the board of an audit 
committee, the mere presence of expert-independent directors has no impact on firm value which could just portray possible "window dressing" of the committee. This is consistent with Aldamen et al (2012) which found evidence that audit committee members with more expertise and managerial experience positively impact firm performance.

As earlier discussed, and to the best of this author's information, there are not many papers examining the association between independent audit committee and bank performance in emerging Asia except for Yeh et al (2011) together with Kallamu and Saat (2015). Nevertheless, both papers employed data from various types of financial institutions and not from banks intrinsically. The scarce available papers in this aspect might be due to general perceptions that this type of study is not really imperative because banks are already heavily regulated (Hassan et al., 2014). Nonetheless the prominent banking controllers still advocate the independence of audit committee especially after the 2007 financial catastrophe and crisis before that as well. The controllers continuously focused on the attributes of audit committee in banks because excessive risks taken by financial institutions were the key contributing factors to the 2007 financial crisis (Yeh et al., 2011). Understanding a subcommittees' attributes that are appropriate for a particular subcommittee is noteworthy since past investigations have shown that several subcommittees were negligent in their oversight of companies prior to major crises in the banking sector (Kallamu \& Saat, 2015).

Based on data of 20 largest financial institutions from G8 countries, Yeh et al (2011) reported that financial institutions with more independent directors on their audit committees registered better performance during the global financial turmoil (2007-2008 only) compared to 2005-06 (ordinary time). Four of the countries belong to the common law system (Australia, Canada, the UK and the US) whereas the other four belong to the civil law system (France, Germany, Italy and Japan). The study reported that the influence of audit committee independence on the bank performance (measured by Stock Returns, ROA and ROE) is particularly better for civil law countries. In addition, it also suggests that the role of committee independence in resolving the excessive risk-taking problems is principally significant whereby they could manipulate the excessive risks by effectively controlling the excess-risk behaviours in their financial institutions to steer away from a crisis.

Alternatively, Kallamu and Saat (2015) examined the impact of audit committee features on the performance of financial institutions in Malaysia both before (1992-1996) and after (20072011) the Malaysian Code on Corporate Governance (MCCG) was issued. The study used data from all entities that listed under finance sector. The article found that audit committee composition enhanced profitability (ROA) of the financial institutions and the result is in line with agency theory that advocates the effective monitoring of the management in reducing possibility for opportunistic behaviour by the management. Nonetheless, the study discovered insignificant influence of independent chair, expertise and executive experience against ROA. Small firms with less complex operations may find the service of expert directors as unnecessary whilst large firms with complex operations may need the service of expert directors (Carcello et al., 2011). In contrast, the insignificant relationship between audit committee characteristics and Tobin's $Q$ may signify that the market does not really value the attributes examined in the paper i.e. the market does not perceive the attributes as valueadding features.

Dissimilar to the positive linkages in the abovementioned prior studies, Romano et al (2012) found significant negative relationship between audit committee independence and banks' performance in term of both ROE and ROA but this result is obtained only using one model, which could be the most robust one namely Fixed Effects with Robust Standard Errors. The 
paper employed data of 25 Italian banking groups which consists of 69 per cent of Italian banking system for 2006-2010. The authors defended the finding by refering to several previous research namely Baysinger and Hoskisson (1990); Denis and Sarin (1999) as well as Ruigrok et al (2006) which had discovered that there were many negative effects of having independent directors on audit committee. More independent audit committees might entail higher costs to the firm, such as travel expenses and stock-options, with a negative influence on banks' performance (Belkhir, 2009). Moreover, outside board members have limited time which resulted in less intimate knowledge on the decision making processes of a firm (Ruigrok et al., 2006). However, it is worthwhile to note that most of the papers that produced negative findings are relatively old studies i.e. conducted before the 2007 financial turmoil.

Conversely, Rambo (2013) for Kenya, Al-Matari et al (2014) for Oman plus Brown and Caylor (2009) for the US indicated that audit committee independence did not significantly affect firm performance. Nonetheless, it is meaningful to note that none of the above theses employed data from Asia emerging nations. Using data from 16 commercial banks from May to July 2010 only, the regression model in Rambo (2013) actually only explained up to 47.8 percent of variance in the financial performance of the banks, as indicated by the co-efficient of determination. Al-Matari et al (2014) employed data of non-financial companies listed in Muscat Security Market (MSM) through 2011 and 2012. According to them, the findings were due to Oman's distinct regulations and environment. Brown and Caylor (2006) linked corporate governance to firm valuation using 1868 firms during 2003-2005 based on 51 internal and external corporate governance provisions provided by Institutional Investor Services (ISS) as of February 1, 2003. Then, they set up a broad summary of measure of corporate governance, namely Gov-Score that are related to accounting including audit committee sole independence. Unexpectedly, none of the measures were positively and significantly related to firm valuation. Nevertheless, they opined that governance factors unrelated to firm value are still important for other beneficial purposes for corporations and their stakeholders. Overall, majority of the above studies documented significant positive relationship between audit committee independence and bank performance whilst none of the negative findings were derived from Asia emerging economies. It is also noteworthy that this governance mechanism was also highlighted by BCBS guidelines (2010) under Key Area FDisclosure and Transparency, Principle 14. In tandem with the aforementioned empirical results, there is a possibility of significant positive relationship between full independent audit committee and bank performance.

\section{Expert-Independent Audit Committee}

As per above literature reviews, most of the papers reported that independent audit committee were significant in improving firm performance as it is vital for good governance and internal control for risks assessments. Nonetheless, not many studies have been executed on the "quality" of the independent directors in the audit committee of banking institutions (Hassan et al., 2018). In other words, there are not many proposals to extend the audit committee competencies from their independence intrinsically, to wider basis. Thus, this article endeavoured to investigate the different yet vital relationship between expertindependent audit committee and bank performance as one of the approaches to measure and thereafter to enhance bank disclosure quality. This paper defines expert-independent audit committee as an audit committee who also holds top management position of another publicly traded firm. 
According to Keys and Li (2005), professional directors who hold multiple directorships improved performance of the hiring firms in 36 months after their appointments. They were also highly demanded as the market might perceive them as having better values due to their more diverse experience, their more generality and their flexibilities in term of easily transferred human capital. It is worthwhile to note that the paper's empirical results signify that the professional directors' valuable human capital offsets their multiple directorships' costs.

Specifically, Chan and Li (2008) together with Aldamen et al (2012) documented that audit committee members with more expertise and managerial experience indeed enhanced firm performance. They opined that these types of audit committees had more exposure to strategic operations of their other firms i.e. more corporate experience. Additionally, they always try to perform the best possible since their performance measurement as director is closely tied with their valued reputational capital in the market. As highlighted in the previous section, Chan and Li (2008) advocated that an audit committee that encompasses a majority of finance-trained directors enhanced firm value almost five times more, against firms with ordinary independent audit committee only. Furthermore, the mere presence of expertindependent directors without independence majority has no impact on firm value which could just portray "window dressing" of an audit committee.

De Vlaminck and Sarens (2013) discovered that there was positive association between number of audit committee members concurrently holding more than three directorships, and the quality of financial statements. This characteristic is most likely another indication of the independence of directors whereby those with several directorships being seen as monitoring specialists via their expertise coupled with experience effects.

Based on previous studies namely Tanyi and Smith (2014), Schmidt and Wilkins (2013) plus Dhaliwal et al (2010), audit committee quality prominently influenced quality of disclosure towards bank performance. An audit committee, especially its chairman is very vital for firm's reporting since they are to be responsible for any financial reporting failure (Schmidt \& Wilkins, 2013) which will mostly ensure their commitment on reporting quality. Dhaliwal et al. (2010) emphasised that an audit committee with accounting expertise, independence and fewer directorships has a profoundly positive impact on financial reporting quality as well as bank performance. Moreover, Chtourou et al (2001) advocated those directors who hold multiple directorships could develop better governance competencies. Consequently, they performed their oversight functions more effectively, resulting in more rigorous management oversight, which in turn, improves the quality of financial reporting (Tanyi \& Smith, 2014). It is also important to note that this governance mechanism was also highlighted by BCBS guidelines (2010) under Key Area F-Disclosure and Transparency, Principle 14. Premised on the above, there might be a significant positive relationship between expert-independent audit committee and bank performance.

\section{Conclusion}

This paper analyses literatures on corporate governance practices and their associations with banks' performances. Prominent emphasis was performed on banks in Asia emerging markets coupled with post 2007 financial crisis period. The empirical literatures on the impact of corporate governance in banking sector has continued to evolve with time in tandem with enhancements of the guidelines by the respective authorities coupled with latest changes in banking industry worldwide. Generally, most of the reviewed studies discovered that the effective corporate governance practices could alleviate banks' performances, particularly 
during/post financial disaster since the practices could enhance the banks' risk management to safeguard their resilience. These observations are envisaged to guide the stakeholders in confirming selected corporate governance evolutions that had mostly affected the banks' performances ahead of the 2007 financial predicament. They can strategize and take necessary actions accordingly, to improve their financial performances.

\section{Reference}

Abd. Rahman, S. A., Yusoff, R., \& Mohamed, W. N. (2009). Environmental disclosure and financial performance: An empirical study of Malaysia, Thailand and Singapore. Social and Environmental Accountability Journal, 29(December 2014), 46-58. http://doi.org/10.1080/0969160X.2009.9651811

Abu, S. O., Okpeh, A. J., \& Okpe, U. J. (2016). Board characteristics and financial performance of deposit money banks in Nigeria. International Journal of Business and Social Science, 7(9), 159-173.

Aebi, V., Sabato, G., \& Schmid, M. (2012). Risk management, corporate governance, and bank performance in the financial crisis. Journal of Banking \& Finance, 36(12), 3213-3226. doi: http://doi.org/10.1016/j.jbankfin.2011.10.020

Agrawal, A., \& Knoeber, C. (1996). Firm performance and mechanisms to control agency problems between managers and shareholders. Journal of Financial and Quantitative Analysis, 31, 377-97.

Aguilera, R. V. (2005). Corporate governance and director accountability: An institutional comparative perspective. British Journal of Management, 16(s1), 39-53.

Akhtaruddin, M., \& Haron, H. (2010). Board ownership, audit committees' effectiveness, and corporate voluntary disclosures. Asian Review of Accounting, 18(3), 245-259. http://doi.org/10.1108/13217341011089649

Aldamen, H., Duncan, K., \& Kelly, S. (2012). Audit committee characteristics and firm performance during the global financial crisis. Accounting and Finance, 52(June 2011), 971-1000.

Al-Matari, Y. A., Al-Swidi, A. K., \& Fadzil, F. H. B. (2012). Audit committee effectiveness and performance of Saudi Arabia listed companies. Wulfenia Journal, 19(8), 169-188.

Al-Matari, E. M., Al-Swidi, A. K., \& Fadzil, F. H. B. (2014). Audit committee characteristics and executive committee characteristics and firm performance in Oman: Empirical study. Asian Social Science, 10(12), 98-113. doi: http://doi.org/10.5539/ass.v10n12p98

Al-Tamimi, H. A. H., Alwan, A. A., \& Abdel Rahman, A. A. (2011). Factors affecting stock prices in the UAE financial markets. Journal of Transnational Management, 16(1), 3-19.

Banham, R. (2000). Top cops of risk. CFO, 16(10), 91-98.

Bart, C., \& McQueen, G. (2013). Why women make better directors. International Journal of Business Governance and Ethics, 8(1), 93.doi: http://doi.org/10.1504/IJBGE.2013.052743

Basel Committee on Banking Supervision (BCBSa). (2010). Principles for enhancing corporate governance (Basel: Bank for International Settlements, October)

Basel Committee on Banking Supervision (BCBSb). (2014). Consultative document-Guidelines: Corporate Governance Principles for Banks (Basel: Bank for International Settlements, October).

Basel Committee on Banking Supervision (BCBS). (2006a). Enhancing corporate governance for banking organisations (Basel: Bank for International Settlements, February). 
Basu, K. (2014). Shifting priorities; building for the future, Global Economic Prospects Vol. 9 (Washington: The World Bank Group).

Battaglia, F., \& Gallo, A. (2015). Risk governance and Asian bank performance: An empirical investigation over the financial crisis. Emerging Markets Review, 25, 53-68. doi: http://dx.doi.org/10.1016/j.ememar.2015.04.004

Baysinger, B., Hoskisson, R. E. (1990). The Composition of board of directors and strategic control: Effects on corporate strategy. Academic Management Review, 15, 72-87.

Bazrafshan, E., Kandelousi, A. S., \& Hooy, C. W. (2015). The impact of earnings management on the extent of disclosure and true financial performance: Evidence from listed firms in Hong Kong. British Accounting Review, 48(2), 206-219. http://doi.org/10.1016/j.bar.2015.09.001

Belkhir, M. (2009), Board structure, ownership structure, and firm performance: Evidence from banking. Applied Financial Economics, 19(19), 1581-93.

Berradino, J. F. (2001). Corporate governance on the agenda. South China Morning Post, 16 April.

Bokpin, G. A. (2013). Ownership structure, corporate governance and bank efficiency: An empirical analysis of panel data from the banking industry in Ghana. Corporate Governance, 13(3), 274-287. doi:http://doi.org/10.1108/CG-05-2010-0041

Boussaada, R., \& Karmani, M. (2015). Did board of directors have an impact on MENA bank performance? International Journal of Economics and Finance, 7(4), 46-56. doi: http://doi.org/10.5539/ijef.v7n4p46

Brancato, C., Tonello, M., Hexter, E., Newman, K. R. (2006). The role of US corporate boards in enterprise risk management. The Conference Board Research Report No. R-1390-06-RR.

Brown, L. D., \& Caylor, M. L (2006). Corporate governance and firm valuation. Journal of Accounting and Public Policy, 25, 409-434.

Brown, L. D., \& Caylor, M. L (2009). Corporate governance and firm operating performance. Review of Quantitative Finance and Accounting, 32, 129-144.

Carcello, J. V., Neal, T. L., Palmrose, Z. V., \& Scholz, S. (2011). CEO involvement in selecting board members, audit committee effectiveness, and restatements. Contemporary Accounting Research, 28(2), 396-430.

Chiang H. T. (2005). An empirical study of corporate governance and corporate performance. Journal of American Academy of Business, 6, 95-101.

Chtourou, S. M., Bedard, J., \& Courteau, L. (2001). Corporate governance and earnings management. (Working Paper), Quebec, Canada: University Laval, Canada.

Claessens, S., \& Yurtoglu, B. B. (2013). Corporate governance in emerging markets: A survey. Emerging Markets Review, 15, 1-33. doi: http://doi.org/10.1016/j.ememar.2012.03.002

De Andres, P., \& Vallelado, E. (2008). Corporate governance in banking: The role of the board of directors. Journal of Banking \& Finance, 32(2008), 2570-2580.

De Vlaminck, N., \& Sarens, G. (2013). The relationship between audit committee characteristics and financial statement quality: evidence from Belgium. Journal of Management and Governance, 19(1), 145-166. http://doi.org/10.1007/s10997-0139282-5

Denis, D. J., \& Sarin, A. (1999). Ownership and board structures in publicly traded corporations. Journal of Financial Economics, 52(2), 187-223.

Dincer, B. (2012). The foreign equity in banking industry and the effectiveness of corporate governance: essential or a soap opera? International Journal of Academic Research in Accounting, Finance and Management Sciences, 2(4), 339-352. 
Elamer, A. A., \& Benyazid, I. (2018). The Impact of risk committee on financial performance of UK financial institutions. International Journal of Accounting and Finance, 8(2), 161-180. doi: 10.1504/IJAF.2018.093290

Ellul, A., \& Yerramilli, V. (2013). Stronger risk controls, lower risk: Evidence from US Bank Holding Companies. Journal of Finance, 68(5), 1757-1803. doi: http://doi.org/10.1111/jofi.12057

ElKelish, W. W., \& Hassan, M. K. (2015). Corporate governance disclosure and share price accuracy. Journal of Applied Accounting Research, 16(2), 265-286. http://dx.doi.org/10.1108/JAAR-02-2013-0015

Erkens, D. H., Hung, M., \& Matos, P. (2012). Corporate governance in the 2007-2008 financial crisis: Evidence from financial institutions worldwide. Journal of Corporate Finance, 18(2), 389-411. doi: http://doi.org/10.1016/j.jcorpfin.2012.01.005

Financial Stability Board. (2013). Thematic review on risk governance, (February). Retrieved from http://www.financialstabilityboard.org/publications/r_130212.pdf

Ghafran, C., \& Sullivan, N. O. (2013). The governance role of audit committees : reviewing a decade of evidence. International Journal of Management Reviews, 15, 381-407. http://doi.org/10.1111/j.1468-2370.2012.00347.x

Ginena, K. (2014). Shari'ah risk and corporate governance of Islamic banks. Corp. Gov. 14 (1), 86-103.

Grant Thornton. (2010). Grant Thornton's corporate governance guidelines for Egyptian banks (Best Practices). (Egypt, October).

Gul, F. A., \& Leung, S. (2004). Board leadership, outside directors' expertise and voluntary corporate disclosures. Journal of Accounting and Public Policy, 23, 351-379.

Hassan, H. (2019). Corporate governance practices and bank performance in Asia emerging market: Post financial crisis. Unpublished PhD dissertation, Universiti Sains Malaysia, Penang, Malaysia.

Hassan, H., Omar, W. M., \& Saad, R. (2014). Contributory determinants influencing total assets of commercial banks in Malaysia (2008-2010). Elixir Fin. Mgmt., 77(2014), 28979-2898.

Hassan, H., Zulkafli, A. H., \& Ibrahim, H. (2018). Corporate Governance of Banks in Asia Emerging Market: A Study on Independent Audit Committee and Liquidity. Global Business \& Management Research, 10(3), 65-74. Retrieved from http://search.ebscohost.com/login. aspx?direct=true \&db=buh\&AN=133618101\&site=e host-live

Hassan, H., Zulkafli, A. H., \& Ibrahim, H. (2019). Corporate governance reform in banking: Risk governance and performance of commercial banks in Asia emerging markets. International Journal of Supply Chain Management, 8(1), 1004-1011.

Hirtle, B. (2007). Public disclosure, risk, and performance at bank holding companies. Staff Reports no. 293, Federal Reserve Bank of New York (July).

Ho, P. L., \& Taylor, G. (2013). Corporate governance and different types of voluntary disclosure: Evidence from Malaysian listed firms. Pacific Accounting Review, 25(1), 4-29. http://doi.org/10.1108/01140581311318940

Hoque, M. Z., Islam, M. R., \& Ahmed, H. (2013). Corporate governance and bank performance: The case of Bangladesh. Social Science Research Network.doi: dx.doi.org/10.2139/ssrn.2208903

Hsu, W., \& Petchsakulwong, P. (2010). The impact of corporate governance on the efficiency performance of the Thai non-life insurance industry. The Geneva Papers on Risk and Insurance Issues and Practice, 35(1), S28-S49. doi: 
http://dx.doi.org/10.1057/gpp.2010.30

Isaksson, M., \& Kirkpatrick, G. (2009). Corporate governance: Lessons from the financial crisis. OECD Observer, 2009(273), 11-12. doi: http://doi.org/10.1787/fmt-v2009-art3-en

Jo, H., \& Kim, Y. (2008). Ethics and disclosure: A study of the financial performance of firms in the seasoned equity offerings market. Journal of Business Ethics, 80(4), 855-878. http://doi.org/10.1007/s10551-007-9473-6

Kallamu, B. S. (2015). Impact of qualification of expert directors on audit. Net Journal of Business Management, 3(3), 43-64.

Kallamu, B. S., \& Saat, N. A. M. (2014). Corporate strategy, corporate governance and performance of financial institutions in Malaysia. Corporate Ownership \& Control, 12(1), 386-398.

Kallamu, B. S. (2015). Impact of qualification of expert directors on audit. Net Journal of Business Management, 3(3), 43-64.

Keys, P. Y., \& Li, J. (2005). Evidence on the market for professional directors. Journal of Financial Research, 28(4), 575-589. doi: http://doi.org/10.1111/j.14756803.2005.00140.x

Khlif, H., Guidara, A., \& Souissi, M. (2015). Corporate social and environmental disclosure and corporate performance. Journal of Accounting in Emerging Economies, 5(1), 51-69. http://dx.doi.org/10.1108/JAEE-06-2012-0024

Kilic, M. (2015). The effect of board diversity on the performance of banks: Evidence from Turkey. International Journal of Business and Management, 10(9).

doi: http://doi.org/10.5539/ijbm.v10n9p182

Kirkpatrick, G. (2009). The corporate governance lessons from the financial crisis. Paper on Financial Market Trends. OECD Steering Group on Corporate Governance.

Kusnadi, Y., Leong, K. S., Suwardy, T., \& Wang, J. (2015). Audit committees and financial reporting quality in Singapore. Journal of Business Ethics, 2001. http://doi.org/10.1007/s10551-015-2679-0

Lakhal, F., Aguir, A., Lakhal, N., \& Malek, A. (2015). Do women on boards and in Top management reduce earnings management? Evidence in France. Journal of Applied Business Research, 31(3), 110

Law Teacher. (2013). Corporate governance, independent directors, agency theory. Retrieved from https://www.lawteacher.net/free-law-essays/company-law/corporat governance-independant-directors-agency-theory-company-law-essay.php?vref=1

Lee, S. P., Isa, M., Ahmad, R., \& Batcha, O. (2018). Corporate governance, risk committee and risk-taking in conventional and Islamic banks. Proceeding of the 20th Malaysian Finance Association Conference. Langkawi: Universiti Utara Malaysia.

Lo, A. W. Y., Wong, R., \& Firth, M. (2010). Can corporate governance deter management from manipulation earnings? Evidence from related-party sales transactions in China. Journal of Corporate Finance, 16, 225-235.

Luckerath-Rovers, M. (2013). Women on boards and firm performance. Journal of Management \& Governance, 17(2), 491-509. doi: https://doi.org/10.1007/s10997-0119186-1

Lundqvist, S. A., \& Vilhelmsson, A. (2018). Enterprise risk management and default risk: Evidence from the banking industry. The Journal of Risk and Insurance, 85(1), 127-157.

Minton, B. A., Taillard, J. P., \& Williamson, R. (2014). Financial expertise of the board, risk taking and performance: Evidence from bank holding companies. Journal of Financial and Quantitative Analysis, 49(2), 351-380. doi: 
http://doi.org/10.1017/S0022109014000283

Mongiardino, A., Plath, C. (2010). Risk governance at large banks: Have any lessons been learned? Journal of Risk Management in Financial Institutions, 3, 116-123.

Ngwenya, S. (2014). Corporate governance and performance of listed commercial banks in South Africa. Corporate Ownership \& Control, 11(2), 677-687.

Nielsen, B. B., \& Nielsen, S. (2013). Top management team nationality diversity and firm performance: A multilevel study. Strategic Management Journal, 34(3), 373-382.

Nuryanah, S., \& Islam, S. M. N. (2011). Corporate governance and performance: evidence from an emerging market. Malaysian Accounting Review, 10(1), 17-42.

Nyamongo, E. M., \& Temesgen, K. (2013). The effect of governance on performance of commercial banks in Kenya: A panel study. Corporate Governance, 13(3), 236-248. doi: http://doi.org/10.1108/CG-12-2010-0107

Olubukunola, U., Uwalomwa, U., Francis, O. I., \& Ehimare, O. A. (2016). Globalizing the board and financial performance: Evidence from Nigerian banks. Indian Journal of Finance, 10(9), 66-71. doi: http://doi.org/10.17010/ijf/2016/v10i9/101481

Peni, E., \& Vahamaa, S. (2012). Did good corporate governance improve bank performance during the financial crisis? Journal of Financial Services Research, 41(1-2), 19-35. doi: http://doi.org/10.1007/s10693-011-0108-9

Piekkari, R., \& Vesanen, T. (2009). Corporate governance and global competitiveness -Within and cross-case analysis. Mimeo, Helsinki School of Economics, Finland.

Polovina, N., \& Peasnell, K. (2015). The effect of foreign management and board membership on the performance of foreign acquired Turkish banks. International Journal of Managerial Finance, 11(3), 359-387. doi: http://doi.org/10.1108/IJMF-06-2014-0086

Praptiningsih, M. (2009). Corporate governance and performance of banking firms: Evidence from Indonesia, Thailand, Philippines, and Malaysia. Jurnal Manajemen Dan Kewirausahaan, 11, 94-108. doi: http://doi.org/10.9744/jmk.11.1.pp. 94-108

Rambo, C. M. (2013). Influence of the capital markets authority's corporate governance guidelines on financial performance of commercial banks in Kenya. The International Journal of Business and Finance Research, 7(3), 77-92.

Romano, G., Ferretti, P., \& Rigolini, A. (2012). Corporate governance and performance in Italian banking groups. Paper to be Presented at the International Conference "Corporate Governance and Regulation: Outlining New Horizons for Theory and Practice, 1-35. Retrieved from http://www.virtusinterpress.org/Full-text-papers.html

Rowe, W., Shi, W., \& Wang, C. (2011). Board governance and performance of Chinese banks. Banks and Bank Systems, 6(1), 26-40.

Ruigrok, W., Peck, S. I. and Keller, H. (2006). Board characteristics and involvement in strategic decision making: Evidence from Swiss companies. Journal of Management Studies, 43(5), 1201-1226.

Sabato, G. (2010). Financial crisis: Where did risk management fail? International Review of Applied Financial Issues and Economics 2, 12-18.

Schmidt, J. \& Wilkins, M. S. (2013). Bringing darkness to light: The influence of auditor quality and audit committee expertise on the timeliness of financial statement restatement disclosures. Auditing: A Journal of Practice \& Theory, 32(1), 221-244.

Setiyono, B., \& Tarazi, A. (2014). Does diversity of bank board members affect performance and risk? Evidence from an emerging market. SSRN. Available at SSRN: http://doi.org/10.2139/ssrn.2491145 
Shungu, P., Ngirande, H., \& Ndlovu, G. (2014). Impact of corporate governance on the performance of commercial banks in Zimbabwe. Mediterranean Journal of Social Sciences, 5(15), 93-105.

Siagian, F. T., \& Tresnaningsih, E. (2011). The impact of independent directors and independent audit committees on earnings quality reported by Indonesian firms. Asian Review of Accounting, 19(3), 192-207. http://doi.org/10.1108/13217341111185128

Srivastav, A., \& Hagendorff, J. (2015). Corporate governance and bank risk-taking. Corporate Governance: An International Review, 1-12.

Staikouras, P. K., Staikouras, C. K., \& Agoraki, M. E. (2007). The effect of board size and composition on European bank performance. European Journal of Law and Economics, 23, 1-27.

Sunday, O., \& Godwin, O. (2017). Effects of board globalising on financial performance of banks in Nigeria. International Journal of Academic Research in Accounting, Finance and Management Sciences, 7(4), 1-10. doi: http://doi.org/10.6007/IJARAFMS/v7-i4/3304

Swamy, V. (2011). Corporate governance and firm performance in unlisted family owned firms. Working papers series, 4(2), 37-52.

Tanna, S., Pasiouras, F., \& Nnadi, M. (2011). The effect of board size and composition on the efficiency of UK banks. International Journal of the Economics of Business, 18(3), 37-41.

Tanyi, P. N., \& Smith, D. B. (2014). Busyness, expertise, and financial reporting quality of audit committee chairs and financial experts. Auditing: A Journal of Practice \& Theory, 34(2), 59-89.

Tarraf, H., \& Majeske, K. (2013). Impact of risk taking on bank financial performance during 2008 financial crisis. Journal of Finance \& Accountancy.

Tee, P. L., Aik, N. C., \& Lim, C. S. (2016). Foreign ownership, foreign directors and the profitability of Malaysian listed companies. Procedia-Social and Behavioral Sciences, 219, 580-588. doi: http://doi.org/10.1016/j.sbspro.2016.05.037

Ujunwa, A. (2012). Board characteristics and the financial performance of Nigerian quoted firms. Corporate Governance: The International Journal of Business in Society, 12(5), 656-674.doi: https://doi.org/10.1108/14720701211275587

Ismail, W. A., Dustan, K., \& Zijl, T. V. (2009). Earnings quality and corporate governance following the implementation of Malaysian code on corporate governance. Available at: www.af.polyu.edu.hk/jcae_af/2010/paper_p/Session\%205.pdf

Walker, D. (2009). A review of corporate governance in UK banks and other financial industry entities Final recommendations, (November), 1-181. http://www.hmtreasury.gov.uk/walker_review_information.

Wasiuzzaman, S., \& Gunasegavan, U. N. (2013). Comparative study of the performance of Islamic and conventional banks. Humanomics, 29(1), 43-60. doi: http://doi.org/10.1108/08288661311299312

Woidtke, T., \& Yeh, Y. H. (2013). The role of the audit committee and the informativeness of accounting earnings in East Asia. Pacific-Basin Finance Journal, 23, 1-24.

Yasser, Q. R., Entebang, H., \& Mansor, S. A. (2011). Corporate governance and firm performance in Pakistan: The case of Karachi Stock Exchange (KSE ) -30. Journal of Economics and International Finance, 3(8), 482-491.

Yeh, Y., Chung, H., \& Liu, C. (2011). Committee independence and financial institution performance during the $2007-08$ credit crunch: Evidence from a multi-country study. Corporate Governance: An International Review 19(5), 437-458. doi: 
http://doi.org/10.1111/j.1467-8683.2011.00884.x

Yu, B., Lenard, M. J., York, E. A., \& Wu, S. (2015). Women leaders in banking and bank risk. Papers presented at World Business Research Conference, Beijing.

Zigraiova, D. (2016). Management board composition of banking institutions and bank risktaking: The case of the Czech Republic. IES Working Paper, 2(2016), 52.

Zulkafli, A. H., \& Hassan, H. (2020). The revision of corporate governance mechanisms and performance of ASEAN banks. Science International (Lahore), 32(4),453-458.

Zulkafli, A. H., Jaaffar, A. H., Hassan, H., \& Ibrahim, H. (2020). Corporate Governance of Banks in Asia Emerging Market: The Relationship between Board Governance Enhancements and Bank Performance. Global Business and Management Research: An International Journal, 12(4), 616-630. 